\title{
Implementation of Indigenous Values of The Bali Aga Villages in Learning as a Modality for Strengthening Nation Character
}

\author{
Ni Ketut Suarni* \\ Department of Guidance and Counseling \\ Universitas Pendidikan Ganesha \\ Bali, Indonesia \\ *niketut.suarni@undiksha.ac.id \\ Kadek Suranata \\ Department of Guidance and Counseling \\ Universitas Pendidikan Ganesha \\ Bali, Indonesia \\ kadek.suranata@undiksha.ac.id
}

\author{
I Ketut Dharsana \\ Department of Guidance and Counseling \\ Universitas Pendidikan Ganesha \\ Bali, Indonesia \\ iketut.dharsana@undiksha.ac.id \\ Gede Nugraha Sudarsana \\ Department of Guidance and Counseling \\ Universitas Pendidikan Ganesha \\ Bali, Indonesia \\ nugraha.sudarsana@undiksha.ac.id
}

\begin{abstract}
The Terunyan Village or already known as Bali Aga village's has a very old tradition. Those traditions need to be inherited through the transformation of knowledge from those who already know and carried out the existing traditions. The purpose of this study was to determine the implementation of the indigenous values of Bali Aga community in Terunyan Village in learning as a modality for strengthening the nation's character. Respondents in this study were 60 students in one of elementary school in Terunyan. This study uses qualitative research methods with a phenomenological approach. Data collection is used the direct observation method. The data analysis is carried out through three steps such as reducing data, displaying data, and drawing conclusions/verification. Based on the results of data reduction, it was found that the implementation of independent values such as the values of caring, peace-loving, cooperation, familiarity, and religious can be categorized as very often applied in learning process. Positive cultural values that grow in the community can still be integrated in learning as modality for strengthening the nation's character. The results of this study have implications for the sustainability of the inheritance of the noble values of society to the younger generation through the education system.
\end{abstract}

Keywords-indigenous, Bali Aga, nation's character

\section{INTRODUCTION}

The world of education is intensively discussing the integration of national character values in the learning process in formal education, explicitly the Minister of Education and Culture has sparked national character values that can be integrated into the learning process or even extracurricular activities in schools. The application of educational values or character to be developed can be integrated with learning indicators [1].

Character is a person's behavior based on values in accordance with the norms prevailing in the society. No exception, Schools in Bali. Bali, which is famous for its thick life customs, is very much based on the Tri Hita Karana philosophy which believes that human life in the world is related to a source of happiness that can cause life to be harmonious. Three dimensions or sources of life's relationship, namely Pahrayangan (man's relationship with God), Pawongan (good human relations between humans), and Palemahan (man's relationship with the environment or nature). Applying the philosophy of everyday life, it is supported by various teachings of life values such as Tri Kaya Parisudha (three basic human ethics consisting of thinking, saying, and doing well), Tat Twam Asi (I am you; you are me, who meant that everyone should love each other as if they love themselves), and Karma Phala (the result of an action). In the last two decades, Balinese society has shown very rapid dynamics and changes, which are caused by the development and influence of modernization and globalization, so that the emergence of an internal phenomenon that encourages changes in Balinese society, specifically the transformation of the agrarian structure. Society becomes an industrial and service society; ecological change, and development of a vision for the Balinese ethnic community through educational advancement. Likewise, external phenomena that drive changes in Balinese society include the influence of telecommunications, transformation, and tourism as well as the intensification of the effects of globalization. 
On the island of Bali, the noble values embodied in customs and religion are contained in physical buildings, daily activities as well as in traditional and religious ceremonies, and this is an ethnopedagogical study in the field of education. Ethnopedagogy is a study that prioritizes the local genius of an ethnic group and becomes a content priority in character education. Ethnopedagogy is also called pedagogic indigenous which is interpreted as a characteristic of parenting based on local values that develop in society. Indigenous values are indigenous values that have a fundamental understanding of facts related to local cultural contexts [2,3]. Indigenous itself is related to the original culture believed by the Bali Aga people who have become habituated and distinguished local culture. The approach in this case includes family, social, and cultural contexts, while the content focuses on meanings, values, and beliefs [3].

Bali is well known as an international tourism area. Various tourist objects have sprung up, and one of the things that attract the attention of foreign tourists is the lifestyle of the Bali Mula/Bali Aga people. Places that often become tourist destinations for tourists are Sidatapa, Sembiran, Cempaga, Padawa and Tigawasa Villages in Buleleng Regency, Tenganan Pagringsingan Village in Karangasem Regency, Pakraman Terunyan Village, and Dausa in Bangli Regency. The village of Bali Aga is generally described as an old village located in the mountains, has a small area, has a linear spatial structure equipped with common spaces, and the Hindu-Javanese influence is still very minimal [4]. By looking at the life of the Balinese people which is supported by the belief in life based on the Tri Hita Karana philosophy which is implemented consistently, it can be predicted that the development of the values of Balinese life leads to dynamically integrated development, namely the development of community life that still maintains original values with modernization or neo-traditional norms.

Terunyan village or in local known as Desa Pakraman also has a unique identity and always looks relatively stable in terms of preserving the values, socio-culture, customs and religions inherited from their ancestors. Terunyan Village is as well a tourist visit village. This has led to an increasingly intensive community interaction with tourists who can have both positive and negative impacts. Terunyan village has its own characteristics when compared to another Bali Mula villages, such as: "the procedure for death for adults who have married and died naturally, are not buried but placed in seven stone holes and fenced with bamboo (ancak saji) under a tree sane and does not smell bad" [5]. The people of Terunyan Village firmly believe that the Menyan tree which has supernatural powers can absorb the smell produced by the body that is placed. This cemetery is an attraction for people outside Terunyan Village to come. The people of Terunyan Village express their diversity by performing ceremonies for offerings to their ancestors. In organizing the ceremony, there are things that are prohibited or recommended, which are listed in the traditional system, both written and unwritten. All these traditions or ceremonies are still being carried out from ancient times to relatives since the existence of Terunyan
Village, such as wedding ceremonies, birth ceremonies, death ceremonies and farming ceremonies.

The ability of the people in Terunyan Village in maintaining traditional socio-cultural values and beliefs is a product of education in the family and society. Thus there is an indication of the uniqueness in the structure, the customary values of the Bali Aga people embedded in Terunyan Village in formal and informal education, which are the main strengths of the Terunyan community's ability to preserve these values. Even though times have developed, the indigenous values of Bali Aga Village will still be the uniqueness inherent in the village. One of the uniqueness is the meaning of Terunyan Village, which is quite unique. It consists of the words "Taru and Menyan". Taru is a fragrant tree. Menyan is a fragrance. So Terunyan is meaning a great fragrance.

The educational process took place in a centripetal habitus, meaning that it is centered on local culture, which gradually increases towards national culture and even global culture [6]. The educational process related to social life, namely living, preserving, developing and implementing the applicable values in accordance with educational goals.

Indigenous values are values of an object of affective mastery in the implementation of knowledge transformation that is oriented towards the inculcation of values for certain objects so that the values of these objects become life guidelines for children. This custom itself is related to the original culture that is believed by the Bali Aga people in Terunyan Village. The cultural existence of the Terunyan people has a unique identity. This means having a culture that differentiates the culture of Pakraman Terunyan Village from other cultures. The content of culture is an element that is included in that culture, which involves the most concrete elements such as material culture, to the abstract, namely values.

Indigenous pedagogy for the people in Terunyan Village uses several traditional methods, including: Mesatua, a learning method that begins with telling a story by an educator, conveying the meaning of the story, expressing about the characters in the story, then summarizing the contents of the story as a life model that has indigenous education values. Megending is a method of parenting by presenting songs in accordance with the child's development phase (sekar rare) according to their needs; learning method with the does (megae) approach, this method is implemented by providing opportunities for children to carry out activities that are relevant to the child's development and safety phase with the aim of forming life skills while assessing the meaning of learning in accordance with the values of the local community [5]. Menyama Braya is a concept of life to live in harmony with each other and comes from the cultural values and customs of the Balinese people. Then to meet educational needs that are innovative but do not eliminate indigenous values, an appropriate learning method is needed.

One of the innovative breakthroughs applied in learning activity is lesson study activities. Lesson study is a model for 
professional development of educators through collaborative and continuous learning assessments based on the principles of collegiality and mutual learning to build a learning community [7]. Lesson study was a collaborative process in a group of teachers when identifying learning problems, designing learning scenarios (including searching for books and articles on topics to be taught), studying students according to scenarios (one teacher doing learning while the other observing), evaluating and revising learning scenarios, reviewing revised learning scenarios, re-evaluating learning and sharing results with other teachers (passing it on) [8]. This lesson study provides an opportunity for teachers to learn and improve their teaching knowledge and skills because here they manage, reflect on lessons, professional competences and other relevant matters $[9,10]$. This opportunity provides teachers with opportunities to understand educational ideas in practice, change their perspectives on learning, and to view their practice from the child's point of view and enjoy the collaborative support among colleagues [10,11]. And what is no less important in the lesson study, the observation and discussion approach after the implementation of learning focuses more on student learning than teacher performance [12].

The teacher learning community is seen as a promising approach to improving systematic learning [13]. Through the application of Lesson Study, it is hoped that teachers will be able to more easily apply Balinese indigenous culture in Terunyan Village through formal education, namely schools. In addition to preserving indigenous cultural values, through Lesson Study activities, it also helps teachers or educators to be able to improve teacher professionalism as teachers based on the principles of continuous professional development and is oriented towards (1) increasing teacher competence, (2) improving the quality of learning, (3) developing learning quality, (4) learning community development, and (5) character development of students. So that lesson study is shared learning, which is the responsibility of educators and parents. Furthermore, effective implementation of character education should provide professional development, promote peer-to-peer interaction, direct teaching or instruction about character, facilitate interpersonal and intrapersonal training, present an explicit agenda that focuses on morality, ethics and clear values, promote family involvement, provide mentors and role models, integrate character education into the school curriculum, and use a multi-strategic approach in every character education program [14]

The characteristics of parenting interactions in indigenous education are based on indigenous psychology, which consists of cognitive theory in which children's development starts from a concrete, pre-operational and formal period. This development begins with thinking about real things in accordance with the original objects, leading to things that are symbolic and abstract in nature. Indigenous pedagogy targets the development of children's learning outcomes based on Bloom's theory, which consists of three stages of development of children's learning outcomes, namely:
1) Cognitive: The target of mastery in indigenous education is knowledge of an object.

2) Affective: Mastery in the implementation of learning is oriented towards instilling values for certain objects so that the object values become a pattern of life for children.

3) Psychomotor: Learning achievement targets is mental skills and real skills that must be possessed by children in these objects so that these skills become a life scale for children.

The indigenous values of the Bali Aga communities are not difficult to implement in the implementation of learning. It's just that it needs to focus on indigenous values like what you want to apply as a capital to strengthen the character of the nation for students. This is because the habituation of the local community is aligned between parenting styles and the implementation of formal education in schools. This education describes the collaboration between formal and informal education. As for the identification of values that describe the character of the nation between the parenting style of parents and education in schools that are often seen in Terunyan Village, such as the care shown to others or a high sense of solidarity, residents work together to help complete the work of other residents and the environment for the village people for productive age work outside the region and leave their children alone with the belief that their children will be cared for by the people around them, accustoming children to prepare for their own needs. This habit is also applied in school. Teachers sometimes direct the same thing to students, namely every Saturday students are asked to clean the school environment and its surroundings, diligently follow religious ceremonies at school, sometimes help teachers, and visit friends who are sick.

The process of transferring culture between generations, from the older generation to the younger generation, contained basic aspirations so that individuals or groups in inheriting the culture could jointly have a core character as their cultural identity, so that cultural identity could survive sustainable. Koentjaraningrat stated that in cultural change, the law of change applies. The more abstract the cultural structures and elements, the slower and more complex the change process will be. Thus structural changes such as value systems, ideologies are always slower than infrastructure such as physical culture. Changes in religious elements are also slower than changes in equipment or livelihood elements. This change will greatly depend on the condition of society whose needs are increasingly complex [15].

\section{METHODS}

This type of research is qualitative research with a phenomenological approach. Qualitative research is research that is useful for obtaining unexpected findings and building a new theoretical framework. Thus, the qualitative approach is a naturalistic approach because the situation in the field is as it is and is not manipulated. The population reduction was done by using simple random sampling method. Respondents in this 
study were 60 elementary school students in Terunyan. Data collection was carried out using direct observation methods. The data analysis procedure was carried out using the analytical step in a phenomenological study which included steps to reduce data, present data, and draw conclusions / verification.

\section{RESULTS AND DISCUSSION}

This research was conducted for knowing the implementation of the indigenous values of the "Bali Aga" community of Terunyan Village in learning as a modality for strengthening the character of the nation.

Terunyan Village is one of the favorite tourist destination in Bali. However, the education level of the population in this area is still low, especially girls. Its citizens are very strong in maintaining the existence, empowerment and resilience of traditional values and beliefs. The people of Pakraman Terunyan Village are very old people who have inherited traditions carried out by their heirs from generation to generation. To inherit existing traditions and develop in society, it is necessary to transform knowledge from previous societies who have known and implemented existing traditions. The knowledge transformation process or educational process will occur in educational institutions such as formal, informal and non-formal institutions.

The people of Terunyan Village are Balinese Aga or Balinese Asli people who have unique customary values, such as: a unique burial tradition, the corpse is not planted but left under a tree. This is in line with the results of research conducted by Dantes et al. that the procedure for the death of adults who have married and died naturally is placed in seven stone holes and fenced with bamboo. In addition, there are other sacred traditions such as Barong Brutuk which is an ancient barong dance that has only existed in Terunyan Village for hundreds of years. The dance depicts the life of the ancestors and is the unen-unen (subordinate) of the ancestors of the Terunyan people. The most striking thing about Barong Brutuk is the clothes they wear. Only dried banana leaves (keraras) but not ordinary banana leaves, but banana leaves plucked from the village of Pinggan. All of these are values that are still preserved as traditions in the life of the people of Terunyan Village. Balinese people, especially "Bali Aga" are rich in wise local values that can enlighten them in carrying out various activities and lives [5].

Based on the results of data reduction in a phenomenological study carried out on the Bali Aga community in Terunyan Village, there are five indigenous values as modalities for strengthening the national character that appears in learning activities and parenting styles that are usually applied by parents at home and in the surrounding environment, which include: 1) concern; 2) peace-loving; 3) cooperation; 4) familiarity; and 5) religious. The majority of these values can be implemented in learning in several subjects shown based on the results of the percentage calculation.
The first value is care. The value of caring can be seen from learning activities inside and outside the classroom. In terms of the people of Terunyan Village, this concern is called "ngerunguang" or "ngerungu". The people of Terunyan Village live in a family atmosphere, with a sense of togetherness of destiny, so they care for each other very highly. In school, one form of concern shown by the teacher is such as "if there are students who are not attending school, the teacher can make home visits, to find out why the students are not attending school. Meanwhile, the concern of fellow students can be seen in the learning interaction. Students with low abilities are guided by students who are more capable, students who are more able to feel responsible to help their friends who do not understand the subject matter become competent." In learning the value of caring, it produces an average of $85 \%$ with very frequent categories.

This is evidenced by the results of interviews conducted with the teacher as follows:

Interviewer: "Occasionally, I see you stroking students' hair, holding their shoulders, chatting on a level with the students. Why did you do that?"

Interviewee: "I did that as a form of my care as a teacher for the students in the class. When a student is confused, I will approach and help him. If there are students who look different than usual, I will also approach to ask what happened. If I have problems, I will help them to study well. Then if there are students who contact me via WhatsApp and ask about homework or assignments that have not been understood, I try to respond. Students have a lot of curiosity, so I don't want to get in the way of the learning process and disappoint him."

Interviewer: "Earlier I saw one of the children who helped his friend make the electrical circuit until it was finished, why did you let that?"

Interviewee: "I let the child help his friend because he knows that his friend has a deficiency in understanding the lesson. He feels sorry for and is responsible for helping his close friends so that he is often seen helping and guiding his friends in completing tasks. From this, I help children to cultivate high concern for others when they see friends who need help."

The second value is love of peace. This can be seen from the existence of rules clearly made by the school and enforced by the teacher regarding student fights at school. The Terunyan people love peace and avoid fighting. This also applies in schools, if there is a dispute between students, the teacher will call students and ask them to shake hands and give directions so that they can make peace with each other. This aims to maintain the relationship between students, teachers and all school members so that they are well maintained. In the classroom, the value of peace is applied through "meditation" activities. When students contemplate with their eyes closed and accompanied by soft music, the teacher enters the teachings of Tat Twam Asi (I am you, you 
are me), the child should not fight, the teacher also includes the words don't hit friends, do not hurt friends, children must love each other friends. In learning the value of peace love, an average of $84 \%$ was generated in the very frequent category.

This is evidenced by the results of interviews conducted with the teacher as follows:

Interviewer: "What is the purpose of being given reflection?"

Interviewee: "Teaching silence so that children are calmer and more ready to learn."

Interviewer: "Is every teaching constantly preceded by a reflection?"

Interviewee: "ot constantly, reflections are done at certain times, because before going to class, the children play, so to calm the students, they are given reflections."

Interviewer: "Can the teacher be rude to the children?"

Interviewee: "I don't think so, because sometimes parents get angry. However, there are also those who leave their children with me. They say their child is naughty, if they are guilty, they can be given any punishment, they want to change. So I dare to punish you standing facing the flagpole."

Interviewer: "Are there any students who dare to fight the teacher (wanen)?"

Interviewee: "There is one child who is now out of school. He hit his friend, when I advised the boy to glare and get angry. If I can't approach the child, usually I will ask another teacher whom he is afraid of to help solve the problem with the friend who was hit."

The third value is cooperation. The teacher trains students to work with each other, through class cleaning activities and the environment around the school which is routinely carried out every day in the morning, as well as cooperation activities to clean the village environment usually once a week. The results of observations also show that school activities begin with cleaning with each other in the school environment, cleaning the classrooms and around the school grounds. You can see students working together with other students to clean the pictures pasted on the classroom walls, sweep and clean the school garden guided by the teacher and the principal. They seemed to really enjoy the activity, indicating that cleaning the school and the school environment is a fun activity for them. In learning the value of this collaboration produces an average of $89 \%$ with very frequent categories.

This is evidenced by the results of interviews conducted with the teacher as follows:

Interviewer: "When teaching, you create groups of four to five people. What's your purpose in doing that?"

Interviewee: "My goal in forming groups is to teach students to respect each other's opinions in solving problems and to share with friends who have experienced difficulties. When studying in groups, they will work together to complete assignments. However, there are also students who do not work, and this is what I need to improve."

Interviewer: "Do you think it is difficult to improve cooperation between elementary school students?"

Interviewee: "I don't think so, especially for my students in class and generally in this village. Children are accustomed to helping each other and working with each other in the village such as "Menyama Braya", cleaning around the village, and we also apply this in school every Saturday. We with each other with the children clean the school environment and its surroundings. In fact, if we have guests, the children will help us to provide food and drink for guests without prompting us."

The fourth value is familiarity. The intimacy of students with other students, as well as between students and teachers is very good, between teachers does provide freedom for students to play, study together, which is important is not noisy, does not damage school facilities, in the interaction of teachers and students such as parents and children, students feel that the teacher is his own parents, and his friends are his siblings, because besides being friends at school, they are also friends outside of school. The results of observations as well show that the interaction between students is very close, as well as interactions between students and teachers who show attachment, if there are teachers who cannot work, even students call or send messages from the teacher why not to school. In learning this familiarity value produces an average of $84 \%$ with very frequent categories.

This is evidenced by the results of interviews conducted with the teacher as follows:

Interviewer: "Do students and teachers have a good relationship?",

Interviewee: "Of course, children already consider us parents themselves. So that when there is any difficulty at school the children do not hesitate to ask questions and ask for help."

Interviewer: "Besides what kind of attachments, do students usually show?"

Interviewee: "Usually, if a teacher doesn't come to the school, the children call them by telephone and ask why. If the teacher's house is close to the school, students will visit the teacher. However, if the house is far away, usually the students send a message."

The fifth value is religion. The teacher invites students to pray when starting and ending learning so that it is given fluency and success. On Hindu holy days, the school holds prayers with all the students at the school, and in the "Piodalan" religious ceremony in Terunyan Village, the school invites students to participate. Children are compliant to the concept of tulah (cursed) if they violate or do not achieve, so they are also very obedient to the cultural traditions of the 
village. Like when there was a Barong Brutuk performance, all students asked to leave school to watch the performance, because they were sure that if they didn't watch, they would be disturbed by curses. Children also have the belief that they are prohibited from traveling to certain places that are considered "sakral" haunted. In learning religious values, it produces an average of $86 \%$ with very frequent categories.

This is evidenced by the results of interviews conducted with the teacher as follows:

Interviewer: "How do you improve students' religious attitudes in the classroom?"

Interviewee: "What I do is invite students to always pray before and after studying. Apart from that, we also invite students to do parade or community service in the temple if there is an Odalan.'

Interviewer: "Is there a belief that is very much held by students, especially in relation to religion?"

Interviewee: "Children really hold onto the belief in the concept of harm (cursed) if they violate, so they are also very obedient to the tradition. Like when there was a Barong Brutuk performance, all students asked permission to leave school to watch the performance, because they were sure and were told by their parents that if they didn't watch they would be disturbed by a curse."

So it can be concluded that there are five character values that are strengthened to develop indigenous values as follows: 1) care; 2) peace-loving; 3) cooperation; 4) familiarity; and 5) religious.

Based on the explanation above, it shows that teachers are not difficult to implement indigenous values as character reinforcement for students. These values are not something new for students, because they have become habits that must be passed down from generation to generation and also applied in learning activities. The goal is that positive cultural values that grow in society can still be integrated in learning as a modality for strengthening the character of the nation.

Furthermore, the learning process carried out through the lesson study setting shows good things. This was shown by the enthusiasm of the students during the learning process. Through the plan, do, and see stages illustrate how the learning process is carefully structured. The planned goals can be achieved. There is a balance in the student learning process to gain knowledge and character formation or good personality in accordance with the values of their ancestors. Teachers also get new learning methods that are not boring. Because in the era of the industrial revolution 4.0, teachers only act as facilitators to transfer knowledge to students. With the sophistication of technology that is presented and the many learning media that can be used, the cultivation of local wisdom values must not be lost and must continue to be preserved in future generations through the field of education. So that later it has implications for the sustainability of the inheritance of the noble values of society to the next generation which are packaged in the education system.

The implication is that it is hoped that in the future good cultural or independent values need to be extracted from several developing cultures, which are not only in Bali Aga but in other areas as well so that informal and formal educations are indeed intertwined in strengthening life and development the values of the character of the nation's successor.

\section{CONCLUSIONS}

Cultivating the original culture of the Bali Aga community in students can help preserve local culture in Bali Mula Village. The application of indigenous culture is integrated in the learning process to facilitate direct interaction between educators and students. Learning is done with the Lesson Study setting. Through the application of Lesson Study, it is hoped that teachers will be able to more easily apply Balinese indigenous culture in Terunyan Village through formal and informal education. There are five character values that are strengthened to develop indigenous values as follows: 1) caring; 2) peace-loving; 3) cooperation; 4) familiarity; and 5) religious.

\section{REFERENCES}

[1] Y. Putranti and M. M. I. Susanti, "Penerapan Program Penguatan Pendidikan Karakter Berbasis Kelas Di Sekolah Dasar Se-Kecamatan Sleman Kabupaten Sleman," Elem. J., vol. 2, no. 1, pp. 42-52, 2019.

[2] E. Istiqomah, "Nilai Budaya Masyarakat Banjar Kalimantan Selatan," J. Psikol. Teor. dan Terap., vol. 5, no. 1, pp. 2087-1708, 2014.

[3] G. S. Aikenhead and M. Ogawa, "Indigenous Knowledge and Science Revisited," Cult. Stud. Sci. Educ., vol. 2, no. 3, pp. 539-620, 2007.

[4] A. P. Parimin, "Fundamental Study on Spatial Formation of Island Village: environmental hierarchy of sacred-profane concept in Bali,' University of Osaka, Osaka, 1986.

[5] N. Dantes, N. K. Suarni, and I. K. Dharsana, "Kajian Etnopedagogi Sesolahan Barong Brutuk di Desa Trunyan," unpublished.

[6] H. A. . Tilaar, Kekuasaan dan Pendidikan: Kajian Menejemen Pendidikan Nasional dalam Pusaran Kekuasaan. Yogyakarta: Rinika Cipta, 2009.

[7] Rusman, Model-Model Pembelajaran Mengembangkan Profesionalisme Guru. Bandung: Raja Grafindo Persada, 2010.

[8] H. Susilo, C. Husnul, J. Ridwan, and Y. Jumiati, Lesson Study Berbasi Sekolah Guru Konservatif Menuju Guru Inovatif. Malang: Bayumedia Publishing.

[9] Y. Fujie, "Lesson Study," in Education in Japan, Singapore: Springer, 2019, pp. 105-123.

[10] A. Wang, S. Yu, M. Wang, and L. Chen, "Effects of a Visualization based Group Awareness Tool on In-service Teachers' Interaction Behaviors and Performance in a Lesson Study," Interact. Learn. Environ., pp. 1-15, 2019.

[11] A. Takahashi and M. Yoshida, "Lesson-study Communities," Teach. Child. Math., vol. 10, no. 9, pp. 436-437, 2004.

[12] F. Baldry and C. Foster, "Lesson Study Partnerships in Initial Teacher Education," Emerald Group Publishing, 2019.

[13] M. Akiba, A. Murata, C. C. Howard, and B. Wilkinson, "Lesson Study Design Features for Supporting Collaborative Teacher Learning," Teach. Teach. Educ., vol. 77, pp. 352-365, 2019.

[14] R. Khoury Aljweid, "Character Education as a Bridge from Elementary to Middle School: A Case Study of Effective Practices and Processes,' Int. J. Teach. Leadersh., vol. 8, 2017.

[15] I. W. Geriya, Transformasi Kebudayaan Bali Memasuki Abad XXI Surabaya: Paramita, 2008 